\title{
HEPATIC CIRCULATION AND HEPATIC FUNCTION DURING ANAESTHESIA AND SURGERY: IV. HALOTHANE ANAESTHESIA
}

\author{
A. GALINDO, M.D., G. F. BRINDLE, M.D., F.R.C.P.(C), AND
}

R. G. B. GILBERT, M.B., CH.B., F.F.A.R.C.S., F.R.C.P.(C)

Hepatic CENTRO-LOBULAR NeCrosts is a non-specific lesion related to liver hypoxia. ${ }^{1-5}$ This lesion depends on the severity and duration of the oxygen deficit. A three-hour period, in healthy dogs, does not produce an injury detectable with the light microscope, ${ }^{6}$ while damage is reported after a continuous six-hour period, or after shorter but repeated exposures to hypoxia. ${ }^{7}$ However, the presence of cellular damage can be detected as early as one hour after the onset, provided the tissue is carefully studied with the electron microscope. ${ }^{8}$

The prognosis of the hypoxic liver lesion depends on its severity ${ }^{9}$ and on the nutritional condition of the liver. ${ }^{10}$ Normal hepatic tissue is capable of complete regeneration even after relatively severe damage. ${ }^{11}$

Centro-lobular necrosis observed after surgery and anaesthesia may be related to liver hypoxia, especially in the presence of metabolic acidosis. ${ }^{12}$ Anaesthesia is a factor which may impair the oxygen supply to the liver, ${ }^{18}$ or it may have a direct "hepato-toxic" effect. Unfortunately, there is little information on the role of the various anaesthetic agents on the development of liver hypoxia or on the role played by anaesthesia and hypoxia in producing hepatic damage. Haley reported no hepatic damage when halothane was given in hypoxic mixtures, ${ }^{14}$ and he later confirmed the increased incidence in hepatic damage when chloroform was administered under similar circumstances. ${ }^{15}$ There were no circulatory, functional, or arterial blood gas studies in these reports.

We have previously shown that the injury produced by chloroform is proportional to the degree of liver hypoxia developed or is associated with its administration. In spite of this, however, a direct toxic effect is also suggested by the presence of hepatic lesions even in the presence of an ideal oxygen supply. The adverse effect of chloroform on hepatic haemodynamics is related to the length of the periods of administration, ${ }^{13}$ to the arterial $\mathrm{CO}_{2}$ tension, ${ }^{6}$ to the systemic haemodynamic changes, and probably to the metabolic acidosis often present during its administration.

The purpose of this study is to assess the effects of halothane on the hepatic circulation and function under normal conditions, and during hypoventilation or metabolic acidosis, and to compare these results with those of similar experiments under chloroform anaesthesia.

\footnotetext{
-Department of Neurology and Neurosurgery, McGill University and The Montreal Neurological Institute and Hospital, Montreal, Quebec.
} 


\section{METHOD}

The hepatic circulation was studied in acute preparations. Hepatic function was studied in chronic preparations.

\section{Acute Preparations}

Twenty-nine mongrel dogs with an average weight of about $14.3 \mathrm{~kg}$. were studied in this group. Anaesthesia was induced with thiopental ( $20 \mathrm{mg} . / \mathrm{kg}$. i. v.), followed by endotracheal intubation and artificial respiration by means of a Bird Mark 8 respirator. Succinylcholine ( 20 to $30 \mathrm{mg}$.) was given intravenously in intermittent doses as needed to maintain controlled respiration. Oxygen 100 per cent was administered during the surgical preparation. Tidal volume, inspiratory pressure, and respiratory frequency were adjusted to maintain an arterial $\mathrm{P}_{\mathrm{CO}_{2}}$ of $40 \mathrm{~mm}$. $\mathrm{Hg} \pm 5 \mathrm{~mm}$. $\mathrm{Hg}$. The right femoral artery and vein were cannulated with polyethylene catheters for arterial pressure recording and intravenous injection of drugs. The dissection of the hepatic artery and the portal vein was carried out through the left eleventh intercostal space, as described in detail elsewhere. ${ }^{12} \mathrm{~A}$ special cardiac catheter was advanced through the right external jugular vein downwards to the hepatic vein; this procedure was assisted and confirmed by direct palpation. Polyethylene catheters were advanced through a gastric vein to the portal and splenic veins respectively.

The hepatic artery blood flow and the portal vein blood flow were determined with a sine-wave electromagnetic blood flow meter. ${ }^{16}$ The readings were expressed in blood-flow units per minute, and calculations were made as relative changes from a given base-line. These measurements were made alternatively in the artery or the vein. A Sanborn low-pressure-differential pressure transducer was connected to a plastic catheter introduced into the portal vein and to an identical catheter in the hepatic vein as described previously. A Statham transducer for blood-pressure determinations was connected to the catheter in the femoral artery. Continuous graphic recordings of the portal or hepatic artery blood flow, arterial blood pressure and differential portal vein to hepatic vein pressures were made via a four-channel Sanborn 150 recording system. Three $\mathrm{ml}$. blood samples were withdrawn every 30 minutes from the femoral artery, portal vein, and hepatic vein, for $\mathrm{pH}, \mathrm{P}_{\mathrm{CO}_{2}}$ and $\mathrm{P}_{\mathrm{O}_{2}}$ determinations by an Instrumentation Laboratory 113 unit. Fresh blood from donor dogs was transfused to the experimental animals whenever the estimated blood loss was greater than $5 \mathrm{c.c} . / \mathrm{kg}$. The oesophageal temperature was maintained at $36^{\circ} \mathrm{C} . \pm 1^{\circ}$.

These acute experiments were divided into control, halothane, and chloroform groups.

Control. Light thiopentone anaesthesia and succinylcholine paralysis were maintained throughout the experiment. The effects of changes of arterial $\mathrm{P}_{\mathrm{CO}_{2}}$ with $\mathrm{O}_{2}$ as the only other gas in the mixture were studied in eight experiments. The range of arterial $\mathrm{P}_{\mathrm{CO}_{2}}$ varied from $14 \mathrm{~mm}$. $\mathrm{Hg}$ to more than $100 \mathrm{~mm}$. $\mathrm{Hg}$.

In four experiments metabolic acidosis, as calculated by the Siggard-Anderson nomogram ( $>-8 \mathrm{mEq} . / \mathrm{L}$.), appeared spontaneously following haemorrhage ( 15 to $20 \mathrm{ml} . / \mathrm{kg}$. blood loss). The arterial $\mathrm{P}_{\mathrm{oO}_{2}}$ was maintained constant and then a 10 per cent $\mathrm{CO}_{2}$ mixture was administered. 
Halothane group. In five experiments halothane anaesthesia was administered by means of a calibrated vaporizer ( 1 to $2.5 \%$ ) at various $\mathrm{CO}_{2}$ tensions. The depth of anaesthesia was arbitrarily stabilized at one-third reduction in mean blood pressure, and complete analgesia with pupils unresponsive to light stimulation. Arterial $\mathrm{P}_{\mathrm{CO}_{2}}$ was changed from $30 \mathrm{~mm}$. $\mathrm{Hg}$ to $80 \mathrm{~mm}$. $\mathrm{Hg}$ by the administration of 5 to 10 per cent $\mathrm{CO}_{2}$ in oxygen.

In three experiments metabolic acidosis was produced during halothane anaesthesia by continuous infusion of $0.5 \mathrm{~N} \mathrm{HCl}$ at the normal arterial $\mathrm{P}_{\mathrm{CO}_{2}}$, until the base deficit as calculated by the Siggard-Anderson nomogram was greater than $-8 \mathrm{mEq} . / \mathrm{L}$.

Chloroform group. In five experiments 5 per cent $\mathrm{CO}_{2}$ was administered under chloroform anaesthesia. Oxygen was given throughout. The criteria for depth of anaesthesia were similar to those described for halothane anaesthesia. Chloroform was administered by means of a calibrated vaporizer (1.5 to $3 \%$ ). In five experiments sodium bicarbonate was given in order to correct the metabolic acidosis found in all these experiments after one hour of chloroform anaesthesia.

Some minor observations were made at the end of some of the chloroform experiments. Intravenous isoproterenol (Isuprel ${ }^{\circledR}$ ) $1 \mu \mathrm{g} . / \mathrm{kg}$, for example, was given on three occasions, while intravenous methoxamine $1 \mu \mathrm{g} . / \mathrm{kg}$. was given in another three experiments. We have previously shown that isoproterenol decreases the vascular resistance in the hepatic artery under normal conditions, while methoxamine has the opposite effect. ${ }^{12}$

\section{Chronic Preparations}

Twenty-seven apparently healthy mongrel dogs with an average weight of about $12 \mathrm{~kg}$. were studied in this group. Care was taken to have a uniform age, weight, and nutritional condition in this group of animals. Each dog was kept and observed in the laboratory building for at least one week before the experiment.

Simultaneous BSP retention test and aspartate transaminase (formerly SGOT) serum levels were made during the observation period. The BSP test consisted of the intravenous injection of bromosulphthaleine $5 \mathrm{mg} . / \mathrm{kg}$. Forty-five minutes later a blood sample was withdrawn and examined in a spectrophotometer. At this time a second blood sample was taken for SGOT serum-level determination. These tests were repeated 24 hours and 48 hours after the end of the experiments. Biopsies from two different liver lobules were taken immediately after the death of the animal. The dogs were sacrificed 48 hours after the experiment by the intravenous administration of nembutal $60 \mathrm{mg} . / \mathrm{kg}$. Four dogs were sacrificed one week after the experiment. Specimens of liver were fixed in 10 per cent formalin. Slices stained with haematoxylin-eosin were graded according to the severity of injury: from no damage- 0 , to severe necrosis -4 . Anaesthesia and ventilation were induced and maintained as in the acute preparations. A plastic "Rochester" 18-gauge needle was inserted in a limb vein. A scalp vein set (18-gauge) was inserted percutaneously into the left femoral artery and connected to a manometer. Three 3-ml. samples of arterial blood were obtained for 
$\mathrm{pH}, \mathrm{P}_{\mathrm{CO}_{2}}, \mathrm{P}_{\mathrm{O}_{2}}$, and $\mathrm{HCO}_{3}-$ determinations, as previously described. The experiment lasted three hours.

The chronic experiments were also divided into control, halothane, and chloroform groups.

Control. Light thiopentone anaesthesia, 100 per cent oxygen, and succinylcholine paralysis were maintained throughout the experiment. Metabolic acidosis was induced in six experiments by a combination of haemorrhage (15 cc. $/ \mathrm{kg}$.) and the intravenous administration of $0.5 \mathrm{~N} \mathrm{HCl}$ solution. The arterial $\mathrm{P}_{\mathrm{CO}_{2}}$ was maintained at $40 \mathrm{~mm}$. $\mathrm{Hg} \pm 5 \mathrm{~mm}$. $\mathrm{Hg}$. At the end of the three hours, the dogs were placed in their cages and observed until sacrifice or death.

Halothane group. Halothane anaesthesia was administered under three conditions: normal, hypoventilation (hypoxia and hypercarbia), and conditions of metabolic acidosis. Depth was judged as in the acute preparations.

In normal halothane anesthesia, the arterial $\mathrm{P}_{\mathrm{O}_{2}}$ was more than $100 \mathrm{~mm} . \mathrm{Hg}$, the $\mathrm{P}_{\mathrm{CO}_{2}} 40 \mathrm{~mm}$. $\mathrm{Hg} \pm 5$, and the $\mathrm{pH} 7.30$ to 7.40. During hypoventilation $\mathrm{P}_{\mathrm{O}_{2}}$ was less than $60 \mathrm{~mm}$. $\mathrm{Hg}$ and $\mathrm{P}_{\mathrm{CO}_{2}}$ more than $45 \mathrm{~mm}$. $\mathrm{Hg}$.

Metabolic acidosis with a base deficit of more than $-8 \mathrm{mEq} . / \mathrm{L}$. (SiggardAnderson nomogram) was induced as in the control group by the combination of haemorrhage and $\mathrm{HCl}$ infusion.

Chloroform group. Depth of anaesthesia was stabilized as in the acute experiments. One hundred per cent oxygen was administered throughout the experiments. The arterial $\mathrm{P}_{\mathrm{CO}_{2}}$ was maintained between 30 and $40 \mathrm{~mm}$. $\mathrm{Hg}$. Sodium bicarbonate was given after the first hour of anaesthesia, as needed, to correct metabolic acidosis. Isoproterenol $1 \mu \mathrm{g}$. $/ \mathrm{kg}$ was given intravenously at the end of each experiment. The combination of isoproterenol and correction of metabolic acidosis reversed the hepatic circulatory disturbances produced by chloroform anaesthesia, i.e., increased blood flow, as observed in the acute experiments. Five dogs were sacrificed in the first 48 hours after the experiment. Four more were maintained for a week and then sacrificed. A fourth set of BSP and SGOT determinations was performed in the one-week group, immediately before sacrifice.

\section{Acute Experiments}

\section{Results}

Table I presents the effect of $\mathrm{CO}_{2}$ accumulation on the hepatic circulation during haemorrhage and halothane anaesthesia. Also included in this table are the results obtained during chloroform anaesthesia after correction of metabolic acidosis. The inhalation of $\mathrm{CO}_{2}$ increased the hepatic artery blood flow from -30.4 to +15.5 per cent, and the portal vein blood flow from -28.7 to +43.5 per cent in the halothane experiments (Fig. 1). The inhalation of $\mathrm{CO}_{2}$ after haemorrhage slightly increased hepatic artery blood flow, from -36 to -26.9 per cent. This increase was greater in the portal vein, from -50 to -11 per cent (Fig. 2). Correction of metabolic acidosis during chloroform anaesthesia reversed the depression of hepatic blood flow induced by this anaesthetic (Fig. 3) in the hepatic artery from -59.1 to -11.4 per cent and in the portal vein from -60.5 to +12.5 per cent. 
TABLE I

\begin{tabular}{|c|c|c|c|c|c|c|c|c|c|c|c|}
\hline \multicolumn{12}{|c|}{ HAEMORRHAGE } \\
\hline \multicolumn{3}{|c|}{ H.A.B.F. } & \multicolumn{3}{|c|}{ P.V.B.F. } & \multicolumn{3}{|c|}{ P.V.-H.V. } & \multicolumn{3}{|c|}{$\mathrm{pH}$ and $\mathrm{PCO}_{2}$} \\
\hline C & $\mathrm{H}$ & $\mathrm{CO}_{2}$ & $\mathrm{C}$ & $\mathrm{H}$ & $\mathrm{CO}_{2}$ & $\mathrm{C}$ & $\mathrm{H}$ & $\mathrm{CO}_{2}$ & $\mathrm{C}$ & $\mathrm{H}$ & $\mathrm{CO}_{2}$ \\
\hline 34 & 22 & 16 & 16 & 9 & 9 & 6 & 5 & 6 & 7.304 & 7.280 & 7.058 \\
\hline 25 & 16 & 20 & 3 & 2 & 5 & 11 & 10 & 14 & 7.310 & 7.275 & 7.117 \\
\hline 29 & 20 & 25 & 8 & 4 & 9 & 9 & 8 & 10 & 7.330 & 7.290 & 6.981 \\
\hline 32 & 19 & 24 & 9 & 3 & 11 & 7 & 5 & 8 & 7.352 & 7.301 & 7.191 \\
\hline 30 & 19. & $\underset{9 \%}{21.2}$ & 9 & 4.5 & 8.5 & 8.2 & 7 & 9.5 & 42.2 & 39.8 & 74.5 \\
\hline
\end{tabular}

\begin{tabular}{|c|c|c|c|c|c|c|c|c|c|c|c|}
\hline \multirow[b]{2}{*}{$\mathrm{C}$} & \multicolumn{11}{|c|}{ HALOTHANE } \\
\hline & A & $\mathrm{CO}_{2}$ & $\mathrm{C}$ & A & $\mathrm{CO}_{2}$ & C & A & $\mathrm{CO}_{2}$ & C & A & $\mathrm{CO}_{2}$ \\
\hline 20 & 17 & 45 & 13 & 9 & 22 & 8 & 7 & 9 & 7.340 & 7.336 & 9.105 \\
\hline 30 & 22 & 38 & 11 & 6 & 12 & 6 & 5 & 7 & 7.380 & 7.340 & 7.195 \\
\hline 35 & 29 & 37 & 5 & 4 & 10 & 9 & 9 & 13 & 7.292 & 7.254 & $\begin{array}{c}7.084 \\
68.3\end{array}$ \\
\hline 35 & 16 & 26 & 8 & 5 & 12 & 6 & 4 & 7 & $\begin{array}{r}7.279 \\
41.8\end{array}$ & $\begin{array}{r}7.202 \\
43.8\end{array}$ & $\begin{array}{l}6.967 \\
80.7\end{array}$ \\
\hline 28 & 19 & 25 & 9 & 6 & 10 & 7 & 5 & 8 & 7.341 & 7.339 & 7.205 \\
\hline 29. & 20 & $\begin{array}{l}34.2 \\
5 \%\end{array}$ & $\begin{array}{r}9.2 \\
-28\end{array}$ & $\begin{array}{r}6 \\
7 \%\end{array}$ & $\begin{array}{l}13.2 \\
.5 \%\end{array}$ & 7.2 & 6 & 8.8 & 43.1 & 42.6 & 65 \\
\hline
\end{tabular}

\begin{tabular}{|c|c|c|c|c|c|c|c|c|c|c|c|}
\hline \multirow[b]{2}{*}{ C } & \multirow[b]{2}{*}{ A } & \multirow[b]{2}{*}{ C.M.A. } & \multirow[b]{2}{*}{ C } & \multirow[b]{2}{*}{ A } & \multicolumn{3}{|c|}{ CHLOROFORM } & \multirow[b]{2}{*}{ C.M.A. } & \multirow[b]{2}{*}{ C } & \multirow[b]{2}{*}{ A } & \multirow[b]{2}{*}{ C.M.A. } \\
\hline & & & & & C.M.A. & C & A & & & & \\
\hline$\overline{28}$ & 13 & 35 & 13 & 2 & 12 & 8 & 3 & 8 & 7.365 & 7.185 & $\begin{array}{r}7.465 \\
33.5\end{array}$ \\
\hline 30 & 12 & 28 & 7 & 3 & 10 & 7 & 2 & 8 & $7 \cdot 375$ & 7.225 & 7.401 \\
\hline 33 & 13 & 22 & 16 & 10 & 14 & 9 & 2 & 7 & $\begin{array}{l}7.1 \\
7.310\end{array}$ & 7.215 & $\begin{array}{c}34.2 \\
7.351\end{array}$ \\
\hline 24 & 8 & 17 & 7 & 3 & 12 & 7 & 2 & 4 & $\begin{array}{r}71.2 \\
7.310\end{array}$ & 7.195 & 7.316 \\
\hline 17 & 8 & 15 & 5 & 1 & 4 & 6 & 2 & 5 & $\begin{array}{r}4.2 .2 \\
7.340\end{array}$ & 7.195 & $\begin{array}{l}41.0 \\
7.382\end{array}$ \\
\hline $\begin{array}{c}\overline{26.4} \\
-59 .\end{array}$ & $\begin{array}{c}10.8 \\
1 \%-11\end{array}$ & $\begin{array}{c}\overline{23.4} \\
1.4 \%\end{array}$ & $\begin{array}{l}9.6 \\
-60.5\end{array}$ & $\stackrel{3.8}{5 \%+1}$ & $\begin{array}{r}\overline{10.8} \\
12.5 \%\end{array}$ & $\overline{7.4}$ & $\overline{2.2}$ & 6.4 & 38.1 & 37.3 & 36.8 \\
\hline
\end{tabular}

$\mathrm{CO}_{2}$ inhalation was given to five of the animals under chloroform anaesthesia. Two of them died during the first ten minutes of $\mathrm{CO}_{2}$ administration due to acute arterial hypotension and ventricular fibrillation; in the remaining three the blood flow was further reduced in both the hepatic artery and the portal vein. 
P.V.P. c $\mathrm{m} \mathrm{H}_{2} \mathrm{O}$

$$
{ }_{0}^{10}[
$$

H.A.B.F.

$$
{ }_{0}^{400}{ }^{300}\left[\begin{array}{c}
200 \\
100 \\
0
\end{array}\right.
$$

A.B.P. $\mathrm{mmHg}$

$$
{ }_{0}^{120}\left[{ }_{0}^{160}\right.
$$



$1 \min$

FIcune 1. Administration of 5 or $10 \% \mathrm{CO}_{2}$ during halothane anaesthesia increased hepatic artery and portal vein blood flows. The increase in portal vein pressure in this figure reflects an increase in blood flow through this vessel. P.V.P. $=$ Portal vein pressure. H.A.B.F. $=$ Hepatic artery blood flow. A.B.P. = Arterial blood pressure.

P.B.F.

$u / \min$



M.A.B.P.
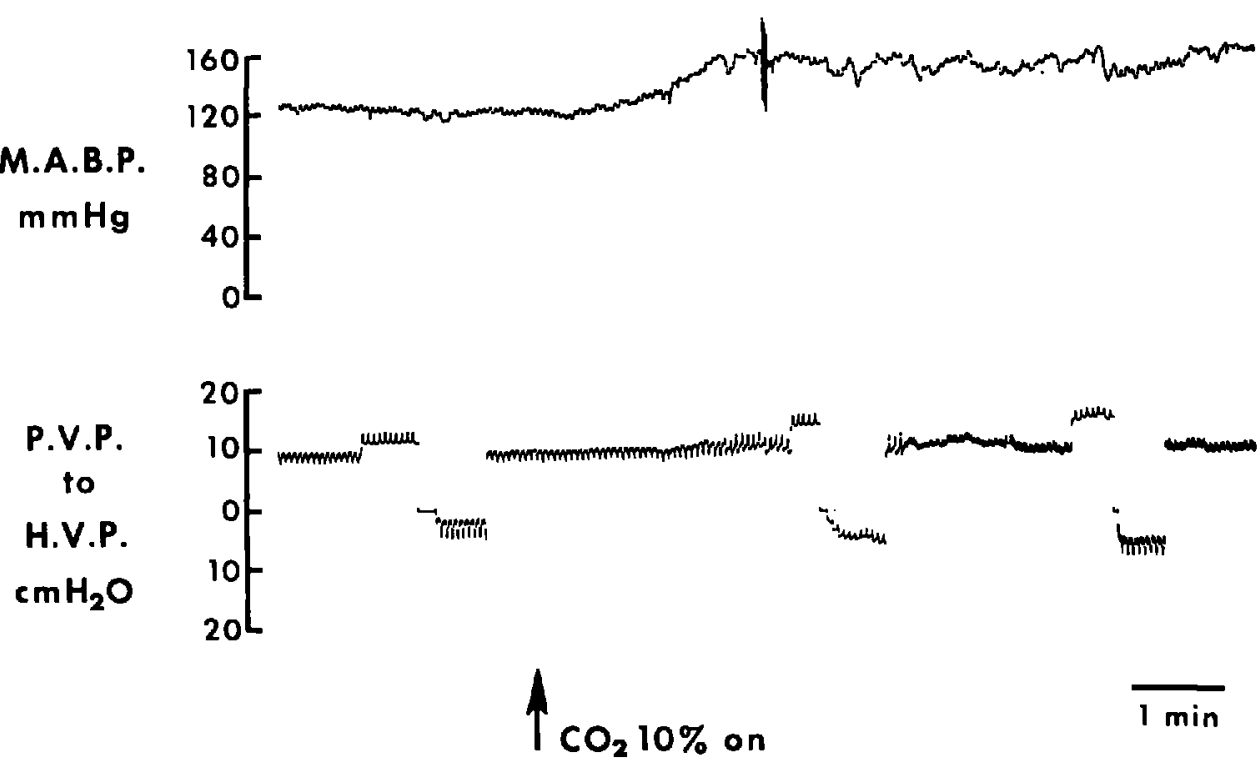

Figure 2. Effect of $10 \% \mathrm{CO}_{2}$ inhalation after mild haemorrhage. There is an increase in trans-hepatic venous pressure despite a greater hepatic vein pressure. The portal vein pressure is increased due to a higher portal vein blood flow. P.B.F. = Portal vein blood flow. M.A.B.P. $=$ Mean arterial blood pressure. P.V.P. to H.V.P. $=$ Differential pressure between the portal and the hepatic vein pressures. Trans-hepatic venous pressure. 

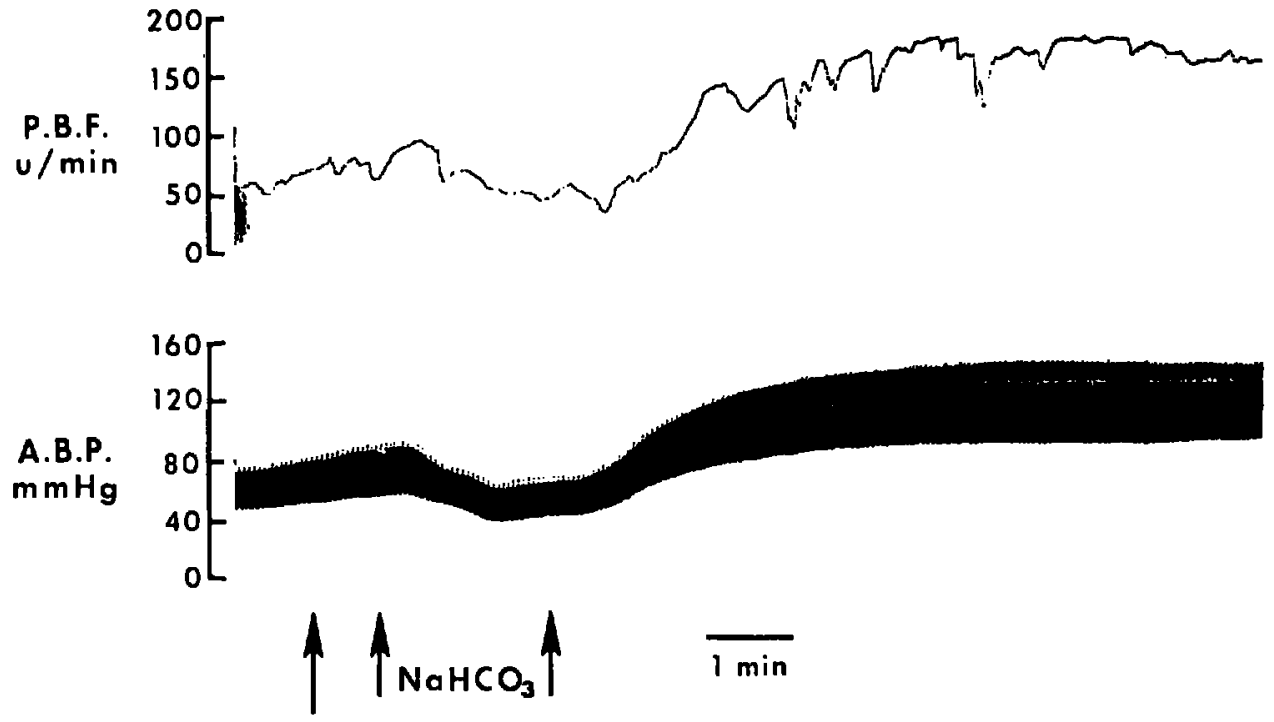

FIGURE 3. Administration $\mathrm{NaHCO}_{3}$ during halothane anaesthesia corrects both the metabolic acidosis and the portal and hepatic artery blood flows. (Key as in Fig. 1.)


Frgure 4. Reversion of the effect of $\mathrm{CO}_{2}$ during chloroform anaesthesia. Inhalation of $5 \%$ carbon dioxide during chloroform anaesthesia decreases the trans-hepatic venous pressure caused by an increase in central venous pressure and a decrease in portal vein pressure. The portal blood flow is greatly reduced. (Key as in Figs. 1 and 2.) 

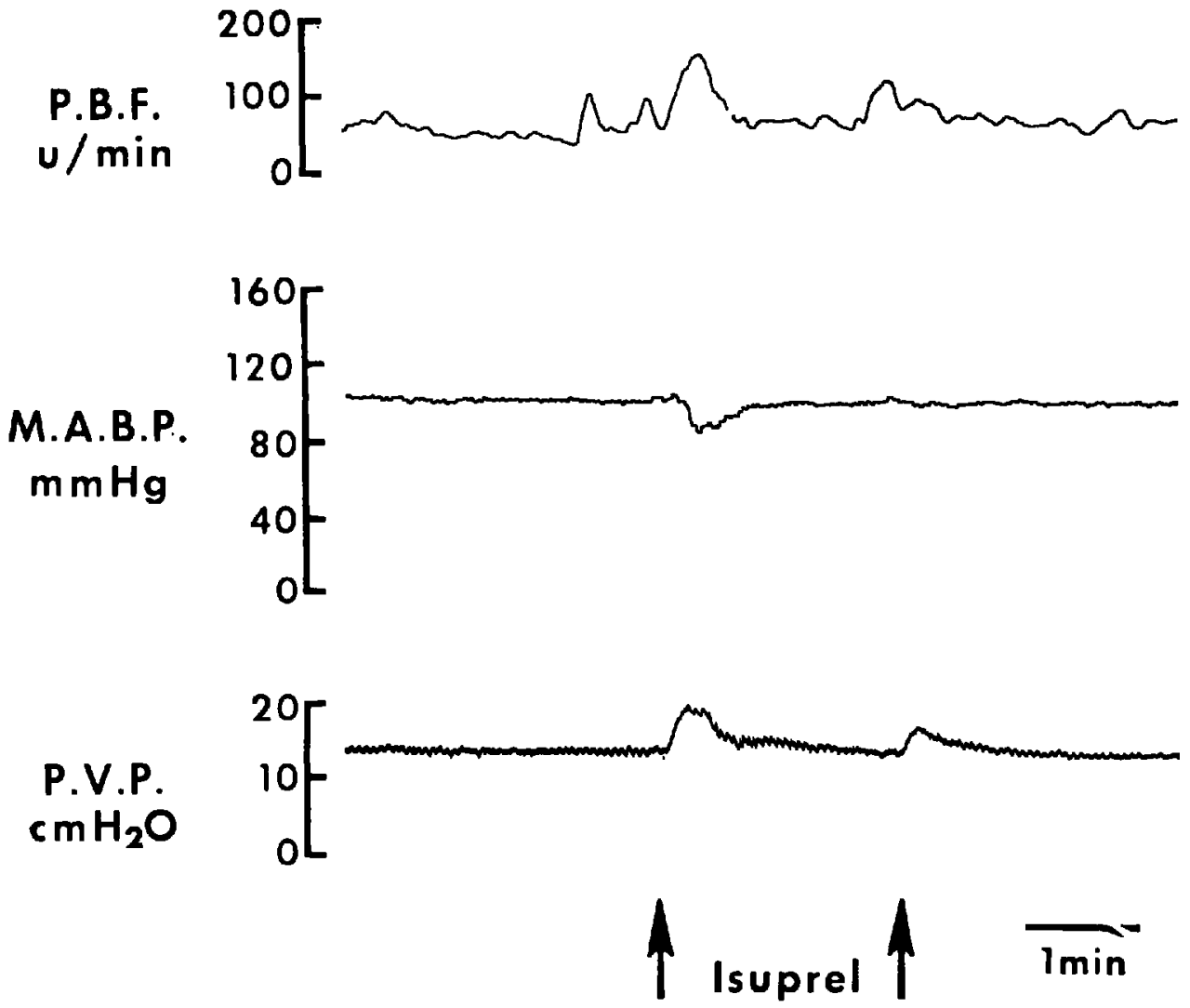

Fic. 5. Isoproterenol (Isuprel) increases both the portal vein and the hepatic artery blood flows. The increase in portal blood pressure is the result of greater blood flow. (Key as in Fig. 2.)

Recovery of these circulatory changes was observed upon termination of $\mathrm{CO}_{2}$ inhalation (Fig. 4).

Hyperventilation in all control experiments leading to an arterial $\mathrm{P}_{\mathrm{CO}_{2}}$ of under $20 \mathrm{~mm}$. Hg resulted in more than 50 per cent reduction in hepatic artery and portal vein blood flow. Administration of 10 per cent $\mathrm{CO}_{2}$ under the same type of respiratory mechanics restored these flows to control levels.

Metabolic acidosis in control experiments as well as in the halothane group, markedly reduced the hepatic blood flow, and if severe enough, led to a marked arterial hypotension.

There was a correlation between the trans-hepatic pressure (portal vein to hepatic vein pressure) and the portal vein blood flow. An increase in this differential pressure was accompanied by greater portal blood flow. Reduction of this differential pressure resulted in lower portal blood flow (Table I).

The reduction in trans-hepatic pressure was due mainly to a decrease in portal vein pressure in the haemorrhage and halothane groups, while in the chloroform experiments it was due to a combination of increase in hepatic vein and decrease in portal vein pressures. 
When catheters were placed in the portal vein and the splenic vein respectively, it was noted that the splenic vein $\mathrm{P}_{\mathrm{O}_{2}}$ varied greatly during 100 per cent oxygen inhalation from $60 \mathrm{~mm}$. $\mathrm{Hg}$ to $450 \mathrm{~mm}$. $\mathrm{Hg}$; that is, from true venous levels to arterial ones. This interesting variation suggests the existence of a shunting effect in the spleen which may affect the portal $\mathrm{P}_{\mathrm{O}_{2}}$ under certain circumstances. In all three experiments in which intravenous isoproterenol was given after chloroform anaesthesia, the hepatic blood flow increased (Fig. 5). The opposite result was observed after intravenous methoxamine (Vasoxyl ${ }^{\circ}$ ).

\section{Chronic Experiments}

Table II summarizes the results obtained in the chronic experiments. No hepatic necrosis or abnormal liver tests were observed in the halothane groups under normal conditions or during hypoventilation. There were small areas of central lobular necrosis when halothane and metabolic acidosis were combined. However, all animals in this latter group were in marked arterial hypotension before sacrifice, as were the control animals in which similar pathology was described. The results of liver tests, when performed, appeared to be in the upper limit of normality.

All chloroform experiments but one showed marked hepatic necrosis when sacrificed during the first 48 hours, or had a healing necrosis when sacrificed one week later. Liver function tests were equally abnormal except in the only animal that escaped necrosis. In this experiment the BSP was abnormal while the SGOT was normal. This animal had to be sacrificed 16 hours after the anaesthetic period due to a respiratory infection that might have influenced the final result.

\section{Discussion}

Metabolic acidosis appeared to be the most important factor capable of depressing the hepatic circulation and inducing hepatic damage.

After halothane anaesthesia hepatic damage was found only in acidotic dogs. But the same damage was also observed in the control group of acidotic animals. Most of the dogs in both groups died after a long period of arterial hypotension (agonal period). It can therefore be assumed from the previous hepatic circulatory studies and from those reported in these experiments, that the cause of this hepatic damage was prolonged liver hypoxia. A further confirmation of this statement can be found in Shoemaker's observations on haemorrhagic shock and hepatic damage. ${ }^{9}$ The length of the hypoxic period, as well as the length of the "agonal period" were critical in the latter author's investigation. Previous studies from this laboratory failed to produce hepatic damage in control animals after short periods of hypoxia. ${ }^{6}$

Chloroform is detected in the liver of rats 48 hours after its administration. ${ }^{17}$ This observation supports our experimental observations on the persistent hepatic circulatory depression that follows the administration of this agent, ${ }^{13}$ and emphasizes the importance of adequate oxygenation in the postanaesthetic period. ${ }^{\circ}$ The administration of oxygen during this period has two objectives: the correction of a deficient oxygen supply during hepatic circulatory depression, and the provision of extra oxygen needed during the hepatic regenerative process with its 
TABLE II

\begin{tabular}{|c|c|c|c|c|c|c|c|}
\hline \multicolumn{3}{|c|}{ BSP } & \multicolumn{3}{|c|}{ SGOT } & & \multirow[b]{2}{*}{ Pathology } \\
\hline $\mathrm{C}$ & $\begin{array}{c}24-48 \\
\text { hrs. }\end{array}$ & $\begin{array}{c}1 \\
\text { week }\end{array}$ & C & $\begin{array}{c}24-49 \\
\text { hrs. }\end{array}$ & $\begin{array}{c}1 \\
\text { week }\end{array}$ & & \\
\hline $\begin{array}{l}\mathbf{2} \\
\mathbf{3} \\
\mathbf{4} \\
\mathbf{3}\end{array}$ & $\begin{array}{l}4 \\
5 \\
6 \\
3\end{array}$ & & $\begin{array}{l}30 \\
20 \\
18 \\
25\end{array}$ & $\begin{array}{l}\text { HALOTHAN } \\
\mathbf{4 5} \\
38 \\
42 \\
\mathbf{3 0}\end{array}$ & $\mathbf{E}$ (norn & $\begin{array}{l}\text { al cond } \\
0 \\
0 \\
0 \\
0\end{array}$ & $\begin{array}{l}\text { itions) } \\
\text { Normal liver } \\
\text { Normal liver } \\
\text { Normal liver } \\
\text { Normal liver }\end{array}$ \\
\hline $\begin{array}{l}3 \\
4 \\
2\end{array}$ & $\begin{array}{ll} & \mathrm{H} \\
\mathbf{6} & \\
\mathbf{3} & \\
\mathbf{5} & \end{array}$ & COTHANI & $\begin{array}{l}\text { (hyp } \\
12 \\
10 \\
38\end{array}$ & $\begin{array}{l}\text { ventilation } \\
25 \\
19 \\
20\end{array}$ & $: \mathrm{PCO}_{2}$ & $\begin{array}{l}>45 \mathrm{~m} \\
0 \\
0 \\
0\end{array}$ & $\begin{array}{l}\mathrm{m} . \mathrm{Hg} ; \mathrm{PO}_{2}<60 \mathrm{~mm} \cdot \mathrm{Hg} \\
\text { Normal liver } \\
\text { Slight congestion } \\
\text { Slight congestion periportal } \\
\text { inflamation }\end{array}$ \\
\hline 6 & 8 & & 41 & 50 & & 0 & Normal liver \\
\hline 2 & 8.6 & HALOTI & $\begin{array}{r}\text { ANE } \\
14\end{array}$ & $\begin{array}{l}106 \\
10 \text { tabolic a }\end{array}$ & cidosis) & $\begin{array}{l}\text { base } d \\
.5\end{array}$ & $\begin{array}{l}\text { eficit }>-8 \mathrm{mEq} . / \mathrm{L} \text {. } \\
\text { Fatty zonal distribution central } \\
\text { congestion }\end{array}$ \\
\hline $\begin{array}{l}4 \\
2 \\
6\end{array}$ & $\begin{array}{l}6 \\
4.6\end{array}$ & & $\begin{array}{l}51 \\
26 \\
19\end{array}$ & $\begin{array}{l}78 \\
24\end{array}$ & & $\begin{array}{l}0 \\
i^{5}\end{array}$ & $\begin{array}{l}\text { Congestion and inflammation } \\
\text { Congestion and inflammation } \\
\text { Congestion and inflammation }\end{array}$ \\
\hline $\begin{array}{l}1.1 \\
5.4 \\
3 \\
5 \\
3 \\
2 \\
1.8 \\
2.5 \\
3.2\end{array}$ & \multicolumn{7}{|c|}{ 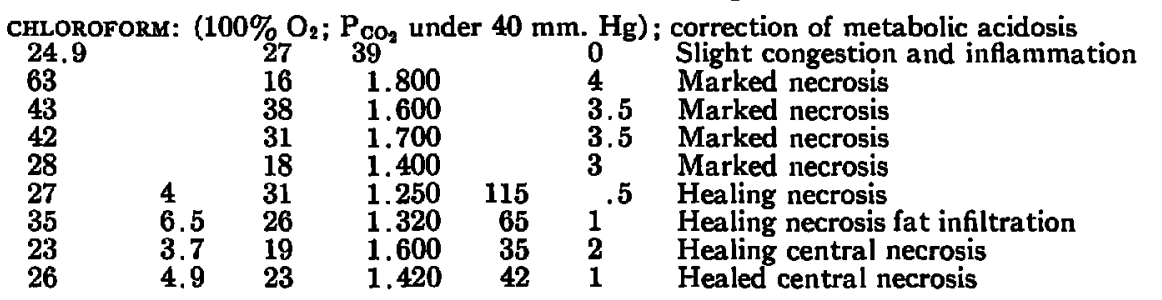 } \\
\hline $\begin{array}{l}5 \\
3 \\
4.5 \\
4 \\
5 \\
5\end{array}$ & $\begin{array}{l}7 \\
6 \\
7\end{array}$ & AEMOR & $\begin{array}{l}\text { GAGE } \\
15 \\
12 \\
30 \\
18 \\
22 \\
31\end{array}$ & $\begin{array}{l}72 \\
66 \\
78\end{array}$ & 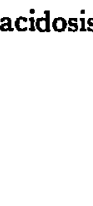 & $\begin{array}{l}\text { base } \\
0 \\
?^{.5} \\
? \\
0 \\
0\end{array}$ & $\begin{array}{l}\text { deficit > }-8 \mathrm{mEq} . / \mathrm{L} . \\
\text { Minimal congestion } \\
\text { Minimal oedema slight inflammation } \\
\text { Focal oedema slight inflammation } \\
\text { Minimal oedema slight congestion } \\
\text { Congestion and infammation } \\
\text { Congestion and inflammation }\end{array}$ \\
\hline
\end{tabular}

$\mathrm{C}=$ Control.

Calculations of base deficit were made by the Siggard-Anderson nomogram.

Liver necrosis was graded from $0=$ normal to $4=$ severe necrosis.

increased oxygen demand. This need would be especially critical in hyperthermic conditions. ${ }^{18}$

After revising previous observations ${ }^{\theta}$ it is still not clear whether chloroform depresses hepatic blood flow directly or indirectly through the production of a metabolic acidosis. The present experiments suggest the latter is more important. However, correction of metabolic acidosis and total recovery of the hepatic blood flow does not prevent the development of hepatic damage. Two possibilities may explain these results: (a) Hepatic blood flow again became depressed after this correction or, more likely, (b) chloroform has two injuring effects on the liver, one circulatory and the other a direct toxic action. The mechanism of this direct toxic action is not well known. Studies with the electron microscope may give final evidence on the histotoxic effect of chloroform. Brauer describes what seems proof of a direct hepatotoxic effect of this agent. ${ }^{19}$ 
One difficulty encountered in clinical as well as experimental observations is the assessment of hepatic function. For obvious reasons a true and complete functional study of the liver requires several tests. However, some of them have greater over-all sensitivity, such as the BSP retention test. This particular test depends on the functional status of the liver cell as well as on the circulation of the dye to the hepatic tissue. Therefore, it can be abnormal owing to non-hepatocellular conditions such as systemic or local hepatic circulatory disturbances.

Active liver cell destruction can be detected by increased serum levels of various enzymes such as aspartate transaminase (formerly SGOT), lactic dehydrogenase (LDH), and alanine transaminase (formerly SGPT). It therefore seems logical to combine the BSP retention test with the determination of serum levels of some of these enzymes on the assumption that: (a) abnormality in both will indicate active hepatic damage of the hypoxic type; (b) BSP abnormality and a normal enzymatic level may be due to an extra-hepatocellular abnormality or to an established hepatic damage; and (c) normal BSP retention test but abnormal enzymatic serum levels may be due to extra-hepatic cellular damage, e.g. heart, muscle etc., or to localized but not functionally important hepatic damage.

Our experimental observations partially confirm these assumptions. The peak abnormality of these two tests coincided with the histological findings confirming the first assumption. The return to normality one week after the administration of chloroform coincided also with the histological findings, indicating the great capability of the hepatic cell for regeneration.

Chloroform and halothane have been considered by some to be indistinguishable in clinical practice. ${ }^{20,21}$ This statement is based on purely clinical observations which are not substantiated under serious experimental conditions. This study as well as previous reports from this laboratory indicate specific differences in both their hepatic and systemic circulatory effects. Carbon dioxide retention during halothane anaesthesia increases hepatic blood flow and systemic arterial blood pressure. Under chloroform both effects are diametrically opposed. ${ }^{6}$

Hypercarbia during halothane anaesthesia in man has been described as a hypotensive combination with increased abnormality in liver function tests. ${ }^{22}$ This observation is at variance with our experimental observations, which indicate that the combination of halothane and $\mathrm{CO}_{2}$ raises arterial blood pressure. It is also at variance with the work of Millar and Morris in which $\mathrm{CO}_{2}$ was shown to increase catecholamine blood levels during halothane anaesthesia. ${ }^{23}$ However, hypercarbia may be the result of respiratory depression and deep anaesthesia; in this condition an over-all cardiorespiratory depression can be expected. Moreover, $\mathrm{CO}_{2}$ has a different systemic and hepatic circulatory effect depending on the acid-base balance, ${ }^{24}$ the anaesthetic agent in use, and the depth of anaesthesia (unpublished observations). Holmes found slight increase in the 45-minute BSP retention test during hypercarbia and nembutal anaesthesia, but failed to explain its mechanism. ${ }^{25}$

The reduction of portal blood flow during halothane anaesthesia was due to a decrease in portal vein pressure, or mesenteric blood flow. On the other hand, during chloroform anaesthesia the portal blood flow fell due to a critical decrease 
in trans-hepatic venous pressure as a result of a higher central venous pressure. Passive congestion of the liver was thus produced.

There is a 100 per cent incidence of hepatic damage with chloroform anaesthesia under circumstances where halothane produces no liver injury. Some degree of metabolic acidosis accompanies all chloroform experiments while no metabolic acidosis develops in the halothane group. Similarly, halothane anaesthesia does not lead to metabolic acidosis in man. ${ }^{26}$ We may conclude that, although chloroform and halothane anaesthesia may seem alike clinically, they have many basic differences in their hepatic effects. No direct hepato-toxic effect resulting from halothane could be found in these experiments unless its administration coincided with prolonged hypoxia and metabolic acidosis.

The systemic circulatory effects of halothane and chloroform are also different. ${ }^{13}$ Studies based on heart rate and blood pressure alone fail to indicate basic differences and may lead to conclusions such as "it was found that it was not possible to identify the agent (chloroform, halothane) solely by means of its clinical effects." 20 We agree with the 1912 A.M.A. report: ". . . use of chloroform for major operations is no longer justifiable."27

\section{SUMMARY}

The circulation of the liver was studied in dogs by means of electromagnetic blood flow meters. Halothane anaesthesia reduces hepatic blood flow under normal conditions. Inhalation of $\mathrm{CO}_{2}$ during halothane anaesthesia increases blood flow in both the hepatic artery and the portal vein. A lesser effect is produced by the inhalation of $\mathrm{CO}_{2}$ immediately after haemorrhage. However, when this gas is administered with chloroform anaesthesia, further decrease in hepatic blood flow occurs.

Metabolic acidosis plays an important role in the reduction of hepatic blood flow in all experimental conditions. Moreover, the blood flow changes produced by chloroform anaesthesia are reversed upon correction of the chloroforminduced metabolic acidosis. However, centro-lobular necrosis occurs in all chloroform animals despite correction of the circulatory impairment.

Some degree of hepatic damage was observed following halothane anaesthesia provided a state of metabolic acidosis existed during its administration. The artificial metabolic acidosis induced in these experiments coexisted with a prolonged period of arterial hypotension before death ("agonal period"). Similar liver pathology was observed in control experiments with haemorrhagic hypotension and metabolic acidosis, without halothane. Hepatic hypoxia is suggested as the common cause of these findings.

There is a correlation between the histological findings and liver function as reflected in the BSP test and SGOT levels.

\section{RÉsumé}

La circulation hépatique fut étudiée chez les chiens au moyen d'un appareil électromagnétique mesurant le débit sanguin. Sous des conditions normales, l'halothane réduit le débit sanguin du foie. L'administration de $\mathrm{CO}_{2}$ durant une 
anesthésie à l'halothane augmente le débit sanguin à la fois dans l'artère hépatique et la veine porte. L'administration de $\mathrm{CO}_{2}$ immédiatement après une hémorragie produit un effet moins prononcé. Cependant, quand ce gas est administré avec une anesthésie au chloroforme, on observe une diminution encore plus marquée du débit sanguin hépatique.

L'acidose métabolique joue un rôle important en ce qui regarde la diminution du débit sanguin que l’on observe au niveau du foie et ceci quelles que soient les conditions de l'experience. De plus, les altêrations du débit sanguin produites par une anesthésie au chloroforme sont corrigées si l'on traite l'acidose métabolique produite par cet agent. Cependant une nécrose centro-lobulaire se produit chez tous les animaux anesthésiés au chloroforme en dépit du fait que la détérioration circulatoire ait été corrigée.

Un certain degré de détérioration hépatique fut observé à la suite d'une anesthésie à l'halothane quand cet agent était administré à des animaux en état d'acidose métabolique. L'état d'acidose métabolique provoque artificiellement au cours de ces expériences, coincide avec une période prolongée d'hypotension artérielle précédant la mort de l'animal ("période d'agonie"). Une détérioration identique du foie fut observée dans des expériences de contrôle dans lesquelles on avait provoqué une hypotension hémorragique et une acidose métabolique mais sans anesthésie à l'halothane. Ainsi l'on suspecte que l'hypoxie hépatique soit la cause commune de ces lésions.

Il existe une correlation entre les manifestations hépatiques et les derangements des fonctions hépatiques, comme on peut le constater avec le test BSP et le niveau sanguin du SGOT.

\section{ACKNOWLEDGMENTS}

We acknowledge with thanks the collaboration of Dr. L. D. Maclean who permitted the use of all surgical facilities at The Royal Victoria Hospital, and of Dr. W. Pirozynski who made the histo-pathological studies of the livers.

The technical assistance of Mrs. Moya Sharpe, Mrs. U. Portner and Mr. R. Widmore is also gratefully acknowledged.

\section{REFERENCES}

1. Myens, J. D. \& Hickam, J. E. An Estimation of the Hepatic Blood Flow and Splanchnic Oxygen Consumption in Heart Failure. J. Clin. Investigation. 27: 620 (1958).

2. Rersum, H. E. Arterial Hypoxemia, Serum Activities of SGOT and SGPT and LDH and Centrolobular Liver Cell Necrosis in Pulmonary Insufficiency. Clin. Sci, 25: 269 (1963).

3. Benrtez, R. M. Degenerative Changes in Liver Associated with Aspiration of Vernix and Myeline Membrane Formation in Lungs in Intrauterine Anoxia. A.M.A. Arch. Pathol. 54: 378 (1952).

4. Myers, J. D.; Brannon, E. S.; \& Holland, B. C. A Correlative Study of the Cardiac Output and the Hepatic Circulation in Hyperthyroidism. J. Clin. Investigation. 29: 1069 (1950).

5. Moone, K. E. \& Brody, T. M. Functional Changes in Liver Mitochondria Following in situ Anoxia. Am. J. Physiol. 198: 669 (1960).

6. Galnndo, A.; Maclean, L. D.; GLbert, R. G. B.; \& Brindle, F. G. Hepatic Circulation and Hepatic Function during Anaesthesia and Surgery: III. Chloroform-Induced Liver Injury. Canad. Anaesth. Soc. J. 12: 443 (1965). 
7. Altmans, H. W. Uber Leververänderungen bein allgemeinem Sauerstoffmangel, nach Unterdruckexperimenten an Katzen. Frankfurt. Ztschr. Path. 60: 366 (1949).

8. Astrond, T. P. \& Burdetre, W. J. Response of the Isolated Perfused Hepatic Parenchyma to Hypoxia. Ann. Surg. 162: 191 (1965).

9. Shoemaker, W. C.; Szanto, P. D.; Frrch, L. B.; \& Brill, N. R. Hepatic Physiology and Morphologic Alterations in Hemorrhagic Shock. Surg., Gynec. \& Obst. 118: 828 (1964).

10. Goldschmmt, S.; Vars, H. M.; \& Ravbin, I. S. The Influence of Foodstuff upon the Susceptibility of the Liver to Injury by Chloroform and Probable Mechanism of Action. J. Clin. Investigation. 18: 227 (1939).

11. Ravdin, I. S.; Thonogood, E.; Reicel, C.; Peters, R.; \& Rhodas, V. E. Prevention of Liver Damage and Facilitation of the Repair in the Liver by Diet. J.A.M.A. 121: 322 (1943).

12. Galnno, A. Hepatic Circulation and Hepatic Function during Anaesthesia and Surgery. I. Hepatic Haemodynamics under Surgical Conditions. Canad. Anaesth. Soc. J. 12: 262 (1965).

13. Galindo, A. Hepatic Circulation and Hepatic Function during Anaesthesia and Surgery. II. The Effect of Various Anaesthetic Agents. Canad. Anaesth. Soc. J. 12: 262 (1965).

14. Haley, F. C. \& Wyant, G. M. The Effect of Halothane on the Liver of Dogs Exposed to Mild Hypoxia. Canad. Anaesth. Soc. J. 6: 271 (1959).

15. HALEY, F. C. Comparison of the Hepatotoxic Effects of Halothane and Chloroform in Hypoxic Dogs. Canad. Anaesth. Soc. J. 10: 352 (1963).

16. Greenfietd, J. C., Jn; Patel, D. J.; Massos, A. J.; \& Fry, D. L. Evaluation of Kolin Type Electromagnetic Flowmeter and the Pressure Gradient Technique. J. Appl. Physiol. 17: 372 (1962).

17. Hellenkant, G. Distribution of Chloroform ${ }^{86} \mathrm{Cl}$ in Mice. Acta pharmacol. et toxicol. 21: 240 (1964).

18. Reed, W. A.; Manning, R. T.; \& Hopins, L. T., JR. Effect of Hypoxia and Hyperthermia on Hepatic Tissue of the Dog. Am. J. Physiol. 206: 1304 (1964)

19. Brauer, R. W. On Effects of Anesthesia on Metabolism and Cellular Functions: A Workshop Held under the Committee on Anesthesia of the National Academy of Sciences-National Research Council. Pharmacol. Rev. 17: 232 (1965).

20. Bamfonth, B. J.; Siebecken, K. L.; Steinfaus, J. E.; \& Orth, O. S. A Clinical Comparison of Chloroform and Halothane by a Blind Study Technique. Anesthesiology. 21: 273 (1960).

21. Dobkin, A. B.; Sxinner, L. C.; \& Jomnston, H. G. A Study of Chloroform Anaesthesia in a Precision System: II. The Effect on Circulatory Dynamics and Anaesthetic Morbidity. Canad. Anaesth. Soc. J. 7 : 379 (1960).

22. Morris, L. E. \& FELDMAN, S. A. Influence of Hypercarbia and Hypotension upon Liver Damage Following Halothane Anaesthesia. Anaesthesia. 18: 32 (1963).

23. Millar, R. A. \& Morrus, M. E. Induced Sympathetic Stimulation during Halothane Anesthesia. Canad. Anaesth. Soc. J. 7: 423 (1960).

24. Carson, S. A. S.; Chonley, G. E.; Hammton, F. N.; Lee, D. C.; \& Morrus, L. E. Variation in Cardiac Output with Acid-Base Changes in the Anesthetized Dog. J. Appl. Physiol. 20: 948 (1965).

25. Holmes, E. L. \& Barnhart, M. I. Effect of Increased Carbon Dioxide Retention on Liver Function in the Dog. J. Appl. Physiol. 13: 184 (1958).

26. Lowenstein, E. Excess Lactate Production during Halothane Anaesthesia in Man. J.A.M.A. 190: 1110 (1964). 